EUROPA REGIONUM TOM XXVIII ROK 2016

DOI: $10.18276 /$ er.2016.28-05

JOLANTA BARBARA JABŁONKOWSKA, JUSTYNA CIEPLIK

Akademia Wychowania Fizycznego Wrocław

\title{
Potencjał turystyczny Uzdrowiska Cieplice Śląskie-Zdrój w ocenie kuracjuszy zagranicznych
}

\section{Wprowadzenie}

W

spółcześnie w europejskiej kulturze popularyzowany jest model życia oparty na „dobrostanie psychofizycznym” (Kowal 2006). Szczególną uwagę poświęca się zagadnieniom aktywności fizycznej, wskazując jej dobroczynne skutki nie tylko dla sprawności ciała, co pozwala jak najdłuższej utrzymać samodzielność i niezależność, lecz także dla sprawności umysłu i równowagi psychiki (Segal, Smyer i Quall, 2010). Propaguje się m.in. działania kształtujące postawę samoakceptacji i samorealizacji poprzez aktywizację turystyczno-rekreacyjną (Vass 2010).

W tym kierunku podąża rynek usługowy, który oferuje coraz bogatszy zakres świadczeń. Rozwija się nowy model uzdrowisk, rezygnujących z jednofunkcyjności (leczenia uzdrowiskowego) na rzecz wielofunkcyjności (Golba 2009), co Kaczmarska określiła jako współczesny model „swoistych rezerwatów zdrowia" (Kaczmarska 2010, s. 57).

Obecnie w Polsce jest prawie 50 miejscowości mających status uzdrowiska. Najwięcej znajduje się na Dolnym Śląsku (aż 11). Co roku przyciągają one wielu kuracjuszy, także z zagranicy. Szacuje się, że co dziesiąty pensjonariusz, odwiedzający polskie uzdrowiska, pochodzi spoza Polski m.in. z Niemiec, Skandynawii, Wielkiej Brytanii, Rosji, Stanów Zjednoczonych czy Kanady. Najchętniej wybierają oni te kurorty, które znajdują się w regionach o wysokim potencjale turystycznym, przede wszystkim w województwach: zachodniopo- 
morskim, dolnośląskim i małopolskim. Niezwykłość i turystyczna atrakcyjność uzdrowisk $\mathrm{w}$ tych regionach stała się na rynkach zagranicznych polskim produktem markowym.

\section{Uzdrowisko Cieplice}

Jednym z najstarszych w Polsce uzdrowisk są Cieplice Śląskie-Zdrój. Początek jego istnienia sięga wieków średnich - 1137 r. (Ładogórski 1963). W 1281 r. książę lwówecki, Bernard Zwinny, przekazał miejscowość nazywaną wówczas „Callidius Fons” (Gorące Źródła) Rycerskiemu Zakonowi Szpitalników Świętego Jana (Joanitom). Jego darowizna była naznaczona szczególnym pragnieniem, aby w tym miejscu zakonnicy leczyli chorych, jak również by informacja o dobroczynnym działaniu gorących wód była rozpowszechniana wśród szerokiej społeczności Europejczyków. W 1381 r. Gotsche Schoff odkupił posiadłości uzdrowiskowe. Niecały wiek później (na początku wieku XV) Hans Schaffgotsch, spadkobierca majątku, podarował jedno ze źródeł Cystersom i rozpoczął działalność leczniczą. W 1537 r. wybudowano pierwszy dom zdrojowy. Powstały dwa oddzielne baseny: dla kobiet tzw. „klasztorny”, dla mężczyzn „hrabiowski”. Wiadomo że w XVI w. gorące źródła przyciągały już wielu kuracjuszy, przede wszystkim z zagranicy. Na początku wieku XVII, gdy Caspar Schwenckfeld, jeleniogórski balneolog i przyrodnik, potwierdził lecznicze właściwości wód z obu źródeł oraz doprecyzował rodzaje schorzeń, które winny być leczone w tym zdroju, kurort stał się jednym z najpopularniejszych i najczęściej odwiedzanych miejsc na Dolnym Śląsku. Sława tego miejsca przyciągała arystokrację, szlachtę, mieszczan z całej Europy (Zieliński 1978). W 1662 r. zburzono starą zabudowę klasztorną i na jej miejsce postawiono nowoczesny budynek przystosowany do potrzeb ówczesnych kuracjuszy. Rozbudowano zaplecze zdrojowe, m.in. dom zwany „Długim domem”, a przy kościele dobudowano dzwonnicę.

$\mathrm{Na}$ początku wieku dziewiętnastego Schaffgotschowie odkupili w całości pocysterski zdrój klasztorny (był to czas niezwykle dynamicznie rozwijającej się masowej turystyki uzdrowiskowej). W ciągu wieku sukcesywnie rozbudowali infrastrukturę komunikacyjną, by codziennie do domów zdrojowych mogli być dowożeni nowi kuracjusze (Kuzio-Podrucki 2013). W połowie wieku Rozalia Saulson wydała pierwszy polski przewodnik turystyczny po uzdrowisku i całych Karkonoszach, zatytułowany „Warmbrunn i okolice jego w 38 obrazach w 12 
wycieczkach przez pielgrzymkę w Sudetach”. W książce tej zamieściła własne propozycje wycieczek całodziennych i półdziennych po okolicy, zaznaczając, iż są to oferty „dla osób bawiących u wód tutejszych, chcących bez nadwyrężenia zdrowia korzystać z piękności okolic Warmbrunn" (Saulson 1850, s. 1). Czas pobytu kuracjuszy w Warmbrunn wynosił przeważnie jeden miesiąc.

Dbając o swych gości Schaffgotschowie zaprojektowali dodatkowe atrakcje, które miały uprzyjemnić kuracjuszom czas wolny przeznaczony na rekreację. Między innymi udostępnili zbrojownię, bibliotekę z 70 tysiącami woluminów, zbiory etnograficzne, mineralogiczne i ornitologiczne (największe w ówczesnej Europie). Miasto szybko się rozwijało. Powstała fabryka maszyn papierniczych i Park Norweski z pawilonem na wzór restauracji w Oslo, powzięto różne inwestycje tj. wybudowano osiedle robotnicze, stary ogród francuski z XVIII w. przekształcono w Park Zdrojowy w stylu angielskim (przylegający do pałacu Schaffgotschów), postawiono budynek teatru w stylu neoklasycznym, który połączono z wybudowaną wcześniej Galerią, w niej mieściły się sala koncertowa, czytelnia, salon gier towarzyskich, palarnia cygar i restauracja (KuzioPodrucki 2007).

W drugiej połowie XIX wieku odwiercono kolejne źródła o temperaturze $44,3^{\circ} \mathrm{C}$. Podniesiono jakość i unowocześniono metody leczenia, stosując najnowocześniejsze sposoby, oparte na wykorzystaniu borowiny, kąpieli kwasowęglowych, elektroterapii. Był to czas największej świetności tego miasta. Stanisław Bełza, pisarz i podróżnik, po wizycie w uzdrowisku pisał: „Z przechadzki wzdłuż i wszerz Warmbrunn wynosi się dodatnie wrażenie. Dwa kościoły, katolicki i protestancki, (...), piękne domy porządne, po większej części dwupiętrowe, gdzieniegdzie ville przypominające stylem południe. Na każdym kroku sklepy, na każdym zakręcie dorożki, na każdym roku posłańcy publiczni. A wszędzie thumy spieszące do kąpieli lub z kąpieli. Promenada jest jednym z czarów tej miejscowości. Zaiste jak na kąpielową miejscowość Szlązka, jest tu wiele i gość przywykły do komfortu wód nadreńskich, lub czeskich, do skarżenia się nie znajdzie tu powodu. (...) Warmbrunn dzisiejszą swoją wielkość bezzawodnie, zawdzięcza głównie swoim zdrowiodajnym źródłom. (...) To też Warmbrunn ma przyszłość przed sobą, z roku na rok ściąga coraz większa liczbę przyjezdnych, a z chwilą gdy został połączony z reszta świata drogą szynową, może być pewnym wzrastającego ciągle powodzenia, zwłaszcza też, że zdrowiodajne jego wody, coraz lepszą markę zdobywają sobie w medycynie" (Bełza 1898 , s. 36-37). 
W okresie od XVI w. do XIX w. kurort odwiedziło wielu wybitnych gości. Byli to zarówno przedstawiciele zamożnej arystokracji, jak i mieszczaństwa z Niemiec, Saksonii, Czech, Pomorza, Litwy, Rosji oraz z Polski. Kroniki uzdrowiska odnotowały obecność m.in. hetmana Stanisława Koniecpolskiego, poety Krzysztofa Opalińskiego, kanclerza wielkiego litewskiego Albrechta Stanisława Radziwiłła, królowej Polski Marii Sobieskiej, polityka i publicysty Hugo Kołlątaja, pisarza i polityka Józefa Wybickiego, bratanka króla Stanisława Poniatowskiego (Rostkowski 1986). Warmbrunn odwiedzita także księżna Izabela Czartoryska, która swój pobyt opisała w dzienniczku pt. ,, Juillet 1816” (Czartoryska 1968).

Dwudziesty wiek nie był okresem łaskawym ani dla miasta, ani dla uzdrowiska. Podczas pierwszej wojny światowej w kurorcie zorganizowano lazaret dla niemieckich żołnierzy, rannych podczas działań wojennych w latach 19141918. Potem zła koniunktura i kryzys, które objęły cały europejski kontynent wpłynęły na ograniczenie zainteresowania kuracjuszy Cieplicami i znaczny spadek liczby odwiedzających. Szczęśliwym okazały się dopiero lata 30. dwudziestego wieku. Miasto w 1935 r. otrzymało prawa miejskie, a liczba jego mieszkańców z roku na rok zwiększała się (by na kilka miesięcy przed II wojną światową osiągnąć szczytowy pułap - 6036 osób) (Terlak 1966). „Okres wojny nie spowodował zniszczeń w mieście. Dopiero później po wkroczeniu Sowietów miasto zostało splądrowane, rozproszono kolekcje Schaffgotschów a uzdrowisko podupadło. (...) W 1948 r. uzdrowisko zostało upaństwowione przez władze komunistyczne. (...) W 1966 r. Cieplice uznano za miejscowość o charakterze uzdrowiskowym. Cztery lata później jako pierwsze na Dolnym Śląsku mogło się poszczycić własnym statutem " (Jasiak 2011). W 1976 r. Cieplice włączono pod administracyjny zarząd Jeleniej Góry.

W 2010 r. działające w mieście „Uzdrowisko Cieplice” zostało sprywatyzowane i stało się własnością podmiotów: KGHM i Funduszu Inwestycyjnego Zamkniętego Aktywów Niepublicznych.

W 2014 r. otwarto w Cieplicach nowe SPA z różnymi basenami termalnymi, park wodny i kompleks saun. Cieplice stanowią doskonały ośrodek kultury (Szybalska-Taraszkiewicz 2015) i bogatą bazę wypadową m.in. w Karkonosze (na Śnieżkę), w Góry Izerskie, do Parków Narodowych (m.in. Doliny Bobru, Chełmy, Rudawskiego), do miejscowości historycznych m.in. do Krzeszowa (opactwo benedyktyńskie), do Jawora i Świdnicy, gdzie znajdują się wpisane na listę UNESCO Kościoły Pokoju, miejscowości górskich (m.in. Karpacza, 
Szklarskiej Poręby, Świeradowa-Zdroju, do najładniejszych zamków i pałaców Dolnego Śląska (np. Chojnik, Bolczów, Niesytno, Świny, Książ). Usytuowanie Cieplic niedaleko granicy z Czechami i Niemcami umożliwia odbywanie jednodniowych wypraw do Pragi, Skalnego Miasta, Harrachova, Drezna.

\section{Materiał i metody}

Wyniki analiz, które zostały zaprezentowane w niniejszym artykule, są efektem badań terenowych, prowadzonych w Cieplicach Śląskich-Zdrój w okresie wiosenno-letnim 2016 r. Dla potrzeb niniejszego badania zastosowano metodę sondażu diagnostycznego przy wykorzystaniu techniki wywiadu. Przeprowadzono rozmowy bezpośrednie z 31 osobami (19 kobietami i 12 mężczyznami) w Parku Zdrojowym i na Placu Piastowskim, w każdą ostatnią sobotę miesiąca od kwietnia do września 2016 r. Osoby zakwalifikowane do badania były w wieku 34-73 lata. Pochodzily z Niemiec (15 osób), Anglii (7 osób), Rosji (4 osoby), Irlandii ( 2 osoby), Holandii ( 2 osoby), Szwecji (1 osoba).

W kwestionariuszu wywiadu postawiono pytania otwarte, dotyczące motywacji udziału w turystyce uzdrowiskowej, subiektywnej oceny wykorzystania potencjału turystycznego przez uzdrowisko Cieplice, warunków materialnobytowych, świadczonych przez usługodawcę, spostrzeżeń i uwag związanych z pobytem w Cieplicach Śląskich-Zdrój. Respondenci mieli możliwość swobodnego uzupetniania treści swych wypowiedzi o dodatkowe spostrzeżenia, jeśli zaistniała taka konieczność.

Uczestnictwo w badaniu było dobrowolne. Należy podkreślić, że ze względu na niezbyt dużą liczbę respondentów, wnioski z badania, nie zostały przedstawione w sposób uogólniony, a jedynie - co zakładano - zarysowano problem i przygotowano podstawy do przeprowadzenia w dalszym etapie szeroko zakrojonych badań.

\section{Analiza wyników}

Respondenci, jako zasadniczy powód wyboru uzdrowiska w Polsce na miejsce letniego wypoczynku, podawali motywy wynikające przede wszystkim z potrzeby poprawy warunków zdrowotnych. Dwadzieścia trzy osoby zdecydowało się na kurort ze względu na odczuwane dolegliwości związane $\mathrm{z}$ niedomaganiami fizycznymi, a osiem - z problemami ze strony układu nerwowego. 
W tej grupie wskazań cztery osoby bardzo wyraźnie wyszczególniły potrzebę przebywania w miejscu „spokoju, ciszy i uspokojenia”, bez zobowiązań i pośpiechu związanego z tempem i trudami dnia codziennego. Kuracjuszka (z Rosji) uzasadniała:

„Proszę mnie dobrze zrozumieć nie jestem słabą osobą. Ale wciąż ktoś ode mnie wymaga więcej. Muszę być sprawna, na każde zawołanie. Nie mogę sobie pozwolić na chorobę, jakąkolwiek słabość. I nie jestem słaba. Ale czasem chciałabym po prostu nie być na pierwszym planie. Odpuścić. Na tydzień wyłączyć się i żeby to ktoś o mnie zadbał. I wie Pani, proszę się nie zdziwić, przyjechałam tu, by być przez tydzień tą słabą, którą ktoś się zaopiekuje. Tu podają mi positki, chodzę na zabiegi, panie są bardzo opiekuńcze, mam czas na swoją słabość. To mój tydzień jak ja to po swojemu nazywam <pieszczoty nad sobą>”.

W odpowiedzi na pytanie: dlaczego właśnie Cieplice Śląskie-Zdrój, stały się miejscem poszukiwania dobrostanu psychofizycznego dla kuracjuszy zagranicznych? podawane były stwierdzenia ogólne, m.in. wskazywano:

- dobrą bazę zabiegową ( 23 wskazania $^{1}$ ),

- lokalizację, blisko granicy i łatwy dojazd (21 wskazań),

- korzystne ceny pobytu (19 wskazań),

- chęć poznania nowego miejsca (17 wskazań),

- zadowolenie z poprzedniego pobytu (13 wskazań),

- atrakcyjną informację w Internecie (8 wskazań),

- sprawną organizację turnusów (4 wskazania).

Do wielu uzasadnień, które mogłyby thumaczyć wybór każdej miejscowości uzdrowiskowej, respondenci dołączyli dwie szczególne motywacje: potencjał turystyczny regionu i miasta oraz jakość zabiegów opartych na naturalnych zasobach. Wyróżniają one istotnie - zdaniem respondentów - Cieplice i tworzą wizytówkę niezbywalnej wyjątkowości dolnośląskiego kurortu oraz jego relewantną cechę wobec innych miast uzdrowiskowych w Polsce.

Potencjał turystyczny miasta i okolicy wskazywali niemal wszyscy respondenci (28 wskazań). Kuracjusze argumentowali:

„Jest to idealny punkt wyjścia w Karkonosze”.

${ }^{1}$ Liczba wskazań się nie sumuje. Można było w odpowiedzi na pytanie o motywy przyjazdu do Cieplic podać kilka powodów. 
„Tu nie można się nudzić. Właśnie tego doświadczam. Wokół same atrakcje. Uwielbiam zwiedzać sąsiednie miasta".

„Niezwykła okolica. Codziennie chodzę uliczkami miasta, po Parku Zdrojowym, Norweskim, po deptaku i jestem urzeczona bezruchem tego miejsca i wiewiórkami”".

„Chodzę po tutejszych górach i zapisuję sobie, co jest niezwykłego w Kotlinie Jeleniogórskiej”.

„Byłam już w niejednym sanatorium, ale tak jak tutaj to nie ma nigdzie. Nie tylko niezwykle piękne i malownicze miejsce, na ulicach zatrzymał się czas a w nim niezwykła magia. Siedzę na deptaku i chłonę ją całą sobą".

Drugim w hierarchii częstotliwości wskazań motywatorem wyboru Cieplic Śląskich-Zdrój na miejsce zadbania o zdrowie stała się „dobra jakość zabiegów za niską cenę" (27 wskazań). Zdanie, które sformułowała jedna z kuracjuszek (z Niemiec), zabrzmiało jak slogan reklamowy, lecz jej opinia nie była jednostkowa i w kontekście innych wypowiedzi uznać ją można za zobrazowanie stanu rzeczywistego. $\mathrm{W}$ wielu bowiem ocenach innych respondentów padały podobne oceny:

„Jestem zachwycona wszystkim co tu doświadczam: od zabiegów i pokoju począwszy po swojskie jedzenie".

„Bardzo przyjazny i co dla mnie ważne niemieckojęzyczny personel w uzdrowisku. Śniadanie w formie bufetu tak różnorodne i dobre jakościowo, że nie jestem w stanie wszystkiego nawet skosztować. Dla mnie ważne też, że jest codziennie świeże. Korzystam z basenu, z sauny, siłowni i chodzę na zabiegi i do Term Cieplickich. Wszystko w dobrym stanie, przygotowane pod oczekiwania gości”.

„W sumie to mało płacimy, a jakość wykonywanych usług jest naprawdę dobra. Za masaż niewiele ponad 10 EURO to dobra cena, a ja wiem, że jestem w dobrych rękach osób z licencją, po studiach fizjoterapii, a nie po jakiś ogólnych kursach".

W uzasadnianiu przyjazdu do Cieplic znalazł się także motywator z grupy potrzeb afiliacyjnych, odnoszących się do poszukiwania wartości, wynikającej z przeszłości - potrzeba nie tyle wspomnień, co realnego powrotu do lat minionych. Opowiadało o niej pięciu respondentów. W ich narracjach Cieplice Śląskie-Zdrój reprezentują czas bezpowrotnie utracony, taki którego szczególnie w rzeczywistości gospodarczo-społecznej Zachodu nie można już odnaleźć. 
Znamienne w tym kontekście wydaje się zdanie kuracjusza (z Niemiec), który opisał swoją motywację przyjazdu pragnieniem powrotu do przeszłości:

„Cieplice to takie trochę zapomniane przez nowoczesną cywilizację miasto. Ale ja chętnie tu wracam. Kiedyś zauroczyło mnie swoim spokojem. Nie lubię tej pchającej się w każdy kąt nowoczesności i hałasu, który za sobą ciągnie. Ja nie jestem tu po raz pierwszy, już tu byłem kilka razy. Wyrywam się z mojego domu, by zaszyć się w tej dawnej epoce. To może sentymentalne, co mówię, ale w Cieplicach czuję jakby czas się zatrzymał i ja razem z nim".

Walor Cieplic jako „miasta retro” padał w wypowiedziach respondentów kilkakrotnie:

„Cieplice mają specyficzny pokomunistyczny klimat. Nie chodzi mi o warunki sanatoryjne, bo poziom jest lepszy niż był choćby jeszcze kilka lat temu. Wyremontowano Dom Zdrojowy. Proszę spojrzeć na samo miasto. Czy jest w tym coś niewłaściwego? nie umiem powiedzieć. Nie wpływa to na obniżenie standardu mojego wypoczywania, traktuję raczej jako specyfikę tego miejsca, może nawetbym dała za ten stan plusik. Bo wszędzie wokoło nowoczesność, a tu pamięć przeszłości”.

„Z zewnątrz wiele budynków wyremontowano, ale w środku, wyposażenie słabe. Jeszcze tu daleko do nowoczesności”.

„Czuje się trochę jak w wieku dwudziestym, i to nawet nie ostatnia dekada. W hotelu drzwi się nie domykają, skrzypią, w recepcji panie mogłyby nauczyć się życzliwości, zwyczajnej uprzejmości wobec klienta, już nie wspominając o znajomości języka angielskiego".

Dwie osoby nie potrafiły doprecyzować szczególnego powodu, który stanowił nadrzędny motywator przy podejmowaniu decyzji o wyborze uzdrowiska:

„Nie wiem, dlaczego akurat tu. Nie miałem szczególnych względów. Tak wyszło. Sugestia biura podróży, które turnus załatwiało”.

„Tu jest zwyczajnie. Chyba nawet przereklamowane. Przyjechaliśmy z ciekawości, bo znajomi byli zachwyceni, ale z przyjemnością stąd wyjedziemy. Kurort jest zaniedbany. Stare to wszystko i bieda wokół. Główny deptak jest ładny, ale reszta miasta zniszczona i zapuszczona. Wolimy nowoczesność, więc powiem wprost: Cieplice nie są dla nas".

Podczas prowadzonych wywiadów respondenci chętnie opowiadali o swoich doświadczeniach pobytu w uzdrowisku. Opisywali czas wolny, który zostaje im po wybraniu dziennych zabiegów. Dlatego podczas rozmowy postawiono 
pytanie, dotyczące sposobów wykorzystania czasu wolnego, by rozpoznać jakie jest zapotrzebowanie kuracjuszy na infrastrukturę turystyczną i rekreacyjną uzdrowiska. Zdecydowana większość respondentów (24 wskazania) podejmuje więcej niż jedną aktywność fizyczną dziennie. Kuracjusze korzystają z basenów sanatoryjnych i Term Cieplickich (29 wskazań), wypożyczają rowery (13 wskazań), wędrują po szlakach pieszych (25 wskazań), odwiedzają obiekty kultury (m.in. muzeum, popularnością cieszą się odkryte w 2015 r. w klasztorze pocysterskim barokowe freski i kościół parafialny z obrazem Willmanna; 14 wskazań). Organizują wyprawy turystyczno-krajoznawcze (26 wskazań). Jedenaście osób przy wyborze wycieczek korzysta z usług biur podróży szczególnie, gdy celem wycieczki są miejscowości położone w znacznej odległości od Cieplic (m.in. w Czechach czy Niemczech). Respondenci chwaląc organizację realizowanych ofert turystycznych, wskazywali jednocześnie też ujemne strony gotowych programów turystycznych - ich sezonową powtarzalność i ograniczoność.

Pozostała grupa osób badanych deklarowała samodzielne zwiedzanie okolicy samochodem bądź komunikacją lokalną:

„Autobusem podjeżdżam do Jeleniej Góry, a stamtąd dalej. Gdzie? Zbyt dużo tego wszystkiego, by wymienić. Ale na pewno Szklarska Poręba, Karpacz, Książ, Świeradów Zdrój - dłuższa wyprawa ale jak widać można”.

„Z mężem jeździmy w chwilach wolnych i oglądamy sąsiednie miejscowości. Byliśmy w hucie w Piechowicach, w Szklarskiej Porębie, na Śnieżce".

„Korzystam z biura turystycznego. Mają bardzo atrakcyjne propozycje, cenowo dobre. A tu wszędzie blisko i do Czech, i do Niemiec. Więc jeżdżę. Bo ze Szwecji to nie tak latwo przyjechać. A tak za jednym pobytem aż trzy kraje sobie zwiedzę".

„Jest tu co zwiedzać. Dwa parki i to blisko budynków sanatoryjnych. Można spacerować po Cieplicach, albo autobusem pojechać do Jeleniej Góry. Jeden turnus to za mało, by wszystko zwiedzić. No w każdym razie tu nie można się nudzić. Okolica piękna,. zachwycająca. Szklarska Poręba - tam są wodospady, w Czechach - Praga, w Niemczech - Drezno, w Bolkowie i Książu - zamek, w Krzeszowie niezwykłe opactwo. Dużo tego. Okolica naprawdę piękna i bogata”.

W czasie wolnym kuracjusze korzystają także $\mathrm{z}$ ofert gastronomicznych i cukierniczych miasta: 
„Polecam naleśnikarnię i koniecznie Borówkę”.

„Jestem prawie codziennym gościem cukierni, takie wypieki tylko tutaj można dostać, muszę się najeść nim wrócę do domu".

„Niesamowita jest pizzeria i cukiernia przy uzdrowisku”.

Biorą udział w masowych imprezach. Szczególnie chwalą dancingi i wieczorki taneczne:

„Rozrywek nie brakuje wszystko zależy, kto i co lubi. Ja czasem bawię się na wieczorkach tanecznych".

„Polecam, jak to się nazywa ..., dyskotekę dorosłego człowieka. Zabawa banalna ale urocza. Już dawno nie pamiętam takiej zabawy. Muzyka skoczna, potańczyć się da do wszystkiego, najważniejsze, że jest towarzystwo".

„Uprzedzono mnie, że w Cieplicach są zabawy taneczne dla różnych grup wiekowych. Dla 60+ w Lalce - spokojne tańce, dla wieku średniego w restauracji zdrojowej. Tam właśnie bywam. No i dla tzw. młodszych pozostaje Polonia - rytmy bardziej dyskotekowe, to nie dla mnie".

Określenie stopnia zadowolenia respondentów $\mathrm{z}$ oferowanych przez uzdrowisko atrakcji turystycznych i rekreacyjnych w ujęciu procentowym w niniejszym badaniu nie jest możliwe i nie było przedmiotem obecnych rozpatrywań. Chodziło raczej o werbalizację sądów kuracjuszy zagranicznych na temat jakości i różnorodności udostępnianych przez uzdrowisko ofert turystycznych czy rekreacyjnych i pozyskanie ich opiniotwórczych głosów na temat zagospodarowania potencjału turystycznego Cieplic.

Potencjał turystyczny uzdrowiska $\mathrm{w}$ ocenie zagranicznych kuracjuszy nie jest należycie wykorzystany i dostatecznie wyeksponowany. Wskazywane przez respondentów mankamenty można odnieść do trzech obszarów potrzeb związanych z:

a) zróżnicowaniem podmiotów gospodarczych, świadczących usługi zdrowotne. Należy:

- rozbudować liczbę sal gimnastycznych, siłowni, klubów fitness, miejsc treningowych, klubów zumby, jogi, które powinny być czynne poza godzinami zabiegów sanatoryjnych i być ogólnodostępne dla wszystkich wypoczywających w uzdrowisku;

- zaopatrzyć je w nowoczesny sprzęt rehabilitacyjny i ogólnorozwojowy, by sprzyjał zwiększeniu aktywności fizycznej kuracjuszy; 
- zwiększyć (szczególnie w sezonie) liczbę prywatnych gabinetów masażu i odnowy biologicznej, Wellness i SPA, bo zbyt małe jest zróżnicowane usług prozdrowotnych;

b) zagospodarowaniem infrastrukturalnym, które ułatwiloby poruszanie się po regionie i zwiększyłoby satysfakcję ze spędzania czasu wolnego. Potrzeba:

- uregulować transport lokalny, zaplanować połączenia komunikacyjne Cieplic z różnorodnymi punktami regionu, by pośrednio budować pozytywny wizerunek regionu, a bezpośrednio - wzmocnić atrakcyjność turystyczną okolicy (np. minibusy czy kolejka wąskotorowa, która stałaby się atrakcją samą w sobie);

- wykreować nowe produkty turystyczne, skierowane nie tylko do odbiorców związanych z turystyką zdrowotną, lecz także aktywną, ekologiczną, wypoczynkową, np. udostępnić dzwonnicę kościelną turystom na punkt widokowy, organizować spływy kajakowe na Bobrze, prowadzić gry miejskie czy krajoznawcze, przygotować punkty obserwowania zwierząt i ptaków;

- zwiększyć działania promocyjne i urozmaicić kanały dotarcia do odbiorców m.in. na portalach społecznościowych;

- poprawić stan nawierzchni dróg dojazdowych do Cieplic i w granicach miasta;

- zwiększyć liczbę stanowisk parkingowych i zmniejszyć dobowe opłaty za korzystanie z nich;

- urozmaicić asortyment w wypożyczalniach sprzętu rekreacyjnego szczególnie pod względem zróżnicowania w sprzęt amatorski i profesjonalny;

- oznakować szlaki turystyczne, zarówno te przeznaczone dla turystyki pieszej, jak i samochodowej;

- przystosować miejsca pieszych wędrówek do potrzeb i możliwości osób niepełnosprawnych, co w uzdrowisku oznaczonym jako kurort dla osób z problemami reumatycznymi i bólami kręgosłupa jest ważnym wyzwaniem (np. utworzyć ścieżki zdrowia ze specjalnymi rozwiązaniami dla osób z chorobami narządów ruchu, silownie zewnętrzne, boiska, minigolf);

c) zwiększeniem, zróżnicowaniem i dostosowaniem ofert kultury (nie tylko masowej) do oczekiwań odbiorców zagranicznych, którzy korzystają z walorów uzdrowiska (w trzech podstawowych językach: angielskim, niemieckim, rosyjskim). Powinno się: 
- zatrudnić na stanowiskach do bezpośredniego kontaktu z kuracjuszami zagranicznymi personel o przynajmniej komunikatywnej znajomości języka angielskiego;

- zauważyć potrzeby kuracjuszy zagranicznych i podawać informacje turystyczne kulturalne, użytkowe $\mathrm{w}$ mieście $\mathrm{i} w$ regionie $\mathrm{w}$ podstawowych językach gości;

- informować o ofertach kulturalnych w językach obcych np. zainicjować popularnonaukowe prelekcje, międzynarodowy uniwersytet letni, stworzyć jarmark międzynarodowy, zatrudnić animatorów czasu wolnego.

\section{Podsumowanie}

Uzdrowisko Cieplice postrzegane jest przez kuracjuszy zagranicznych jako miejsce, gdzie można nie tylko odzyskać zdrowie, lecz także wśród niezwykłego bogactwa i różnorodności turystycznej regionu wzmocnić siły psychofizyczne. Potencjał turystyczny Cieplic Śląskich-Zdrój jednakże - w ich ocenie - nie został jeszcze w pełni wykorzystany. Dziś do uzdrowiska przyjeżdżają nie tylko osoby, nastawione na leczenie sanatoryjne ze względu na dolegliwości zdrowotne. Świadomość potrzeby dbania o swój dobrostan, kieruje do uzdrowiska coraz większą grupę osób w różnych przedziałach wiekowych, o różnych potrzebach i z różnych kręgów kulturowych; nastawione na relaks w środowisku naturalnym i czynny wypoczynek poprzez podejmowanie różnorodnych form aktywności turystycznej i rekreacyjnej.

Dawna więc jednofunkcyjność uzdrowiska, związana z tradycyjnym lecznictwem sanatoryjnym, jest zdaniem kuracjuszy zagranicznych niewystarczająca. Wymaga ciągłego stopniowego wzbogacania o innowacyjne produkty i usługi, które będą klienta wspierały w pozyskiwaniu i utrzymaniu dobrostanu. Wskazują wyraźnie, że zmian wymagają m.in. infrastruktura komunikacyjna, drogowa tak w samym mieście jak i w regionie; rozbudowy i zróżnicowania szlaki piesze, rowerowe i obiekty rekreacyjne, które umożliwiłyby łączenie turystyki uzdrowiskowej z poznawczą i aktywną formą (rekreacyjną) spędzania czasu wolnego. 


\section{Bibliografia}

Bełza S., W Górach Olbrzymich. wyd. 2, Gebethner i Wolff. Kraków 1898.

Czartoryska I., Dyliżansem przez Śląsk: dziennik podróży do Cieplic w roku 1816. tł. J. Bujańska. Zakład Narodowy im. Ossolińskich. Wrocław 1968.

Golba J., Gospodarka przestrzenna w uzdrowiskach i wielofunkcyjność uzdrowisk największym wyzwaniem dla samorządów w: Innowacyjne kierunki rozwoju turystyki uzdrowiskowej i lecznictwa uzdrowiskowego. Stowarzyszenie Gmin Uzdrowiskowych RP, Muszyna 2009, s. 109-114.

Jasiak K., Dzieje cieplickiego uzdrowiska w niemieckiej i polskiej historiografii. Zarys problemu. Turystyka, SportiZdrowie, nr 1. http://tsz.po.opole.pl/?d=12\&nid=7\&l=pl. (dostęp 2011).

Kaczmarska A., Uwarunkowania i tendencje zmian $w$ rozwoju uzdrowisk $w$ Polsce. w: A. R. Szromka (red.), Uzdrowiska $i$ ich znaczenie $w$ gospodarce Turystycznej, Proksenia, Kraków 2010. s. 55-76.

Kowal J., Polska turystyka uzdrowiskowa w liczbach. w: T. Iwanek (red.), Turystyka uzdrowiskowa $w$ gospodarce regionu i kraju. Wyższa Szkoła Zarządzania, Wrocław 2006. s. 151-169.

Kuzio-Podrucki A., Schaffgotschowie. Zmienne losy śląskiej arystokracji. Oficyna Monos - Tarnowskie Góry. Bytom 2007.

Kuzio-Podrucki A., Schaffgotschowie. Panowie na Chojniku i Cieplicach. Ad Rem i uzeum Przyrodnicze, Jelenia Góra 2013.

Ładogórski T,. Geneza miasteczka Cieplice Śląskie-Zdrój, Acta Universitatis Wratislaviensis, Studia Geograficzne, nr 9, 1963. s. 115-128.

Rostkowski H.W., Stynni ludzie w Polskich uzdrowiskach. Ludowa Spółdzielnia Wydawnicza. Warszawa 1986.

Saulson R., Warmbrunn i okolice jego w 38 obrazach zebranych w 12 wycieczkach przez Pielgrzymkę w Sudetach, Korn: Wilhelm Gottlieb - dziedzice. Wrocław 1850.

Segal D.L., Smyer, M.A., Quall, S.H., Aging and Mental Health, Understanding Aging, wyd. 2, Hoboken, New York 2010.

Szybalska-Taras zkiewic z M., Problematyka dotyczaca Uzdrowiska Cieplice realizowana w gatunkach dziennikarskich na łamach ,Nowin Jeleniogórskich” w latach 2009 2012 w: M. Szybalska-Taraszkiewicz, M. Ursel, A. Woźny (red.). Uzdrowiska Dolnego Śląska. Wizerunek - Marketing - Media. Karkonoska Państwowa Szkoła Wyższa w Jeleniej Górze. Jelenia Góra 2015.

Terlak M., Cieplice Śląskie Zdrój i okolice. wyd. 3, Sport i Turystyka, Warszawa 1966.

Vass J., Breaking the Age Barrier, National Institute of Adult Continuing Education, t. 21, nr 10, 2010. s. 8-10.

Zieliński A., Polskie podróże po Śląsku w XVII i XVIII wieku. Ossolineum, Wrocław 1978. 


\section{Tourist potential of Cieplice Śląskie-Zdrój health resort in the opinion of foreign patients \\ Summary}

The study presents an assessment of the tourism potential of Cieplice Slaskie-Zdroj health resort by foreign patients, who participated in treatment courses in the springsummer period in 2015. Cieplice is the oldest Lower Silesian resort dating back to 1137 . It flourished in the eighteenth century. Since that time, the spa has been continuously visited by many guests from all over Europe because of the wealth of natural and tourist resources and its beautiful landscape. The study made it possible to assess the uniformity of functionality of Cieplice, its quality realized today and preserved throughout the centuries. Furthermore, expectations of foreign patients were diagnosed towards the development and use of tourist facilities and recreational opportunities of the spa.

Translated by Justyna Cieplik 